Article

\title{
Intra-/Intermolecular Bifurcated Chalcogen Bonding in Crystal Structure of Thiazole/Thiadiazole Derived Binuclear (Diaminocarbene)Pd ${ }^{\mathrm{II}}$ Complexes
}

\author{
Alexander S. Mikherdov ${ }^{(D)}$, Alexander S. Novikov ${ }^{(D)}$, Mikhail A. Kinzhalov ${ }^{(D)}$, \\ Andrey A. Zolotarev and Vadim P. Boyarskiy * (D) \\ Saint Petersburg State University, $7 / 9$ Universitetskaya Nab., Saint Petersburg 199034, Russian Federation; \\ asm93@yandex.ru (A.S.M.); ja2-88@mail.ru (A.S.N.); m.kinzhalov@spbu.ru (M.A.K.); \\ a.zolotarev@spbu.ru (A.A.Z.) \\ * Correspondence: v.boiarskii@spbu.ru; Tel.: +7(812)428-68-90
}

Received: 26 January 2018; Accepted: 24 February 2018; Published: 27 February 2018

\begin{abstract}
The coupling of cis-[PdCl2(CNXyl)2] ( $\mathrm{Xyl}=2,6-\mathrm{Me} 2 \mathrm{C} 6 \mathrm{H} 3)$ with 4-phenylthiazol-2-amine in molar ratio 2:3 at $\mathrm{RT}$ in $\mathrm{CH} 2 \mathrm{Cl} 2$ leads to binuclear (diaminocarbene)PdII complex 3c. The complex was characterized by HRESI+-MS, 1H NMR spectroscopy, and its structure was elucidated by single-crystal XRD. Inspection of the XRD data for $3 c$ and for three relevant earlier obtained thiazole/thiadiazole derived binuclear diaminocarbene complexes (3a EYOVIZ; 3b: EYOWAS; 3d: EYOVOF) suggests that the structures of all these species exhibit intra-/intermolecular bifurcated chalcogen bonding (BCB). The obtained data indicate the presence of intramolecular $\mathrm{S} \bullet \bullet \bullet \mathrm{Cl}$ chalcogen bonds in all of the structures, whereas varying of substituent in the 4th and 5th positions of the thiazaheterocyclic fragment leads to changes of the intermolecular chalcogen bonding type, viz.

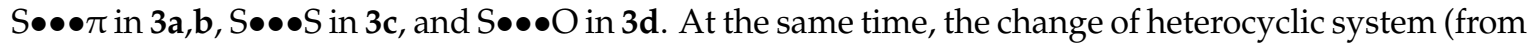
1,3-thiazole to 1,3,4-thiadiazole) does not affect the pattern of non-covalent interactions. Presence of such intermolecular chalcogen bonding leads to the formation of one-dimensional (1D) polymeric chains (for $\mathbf{3 a}, \mathbf{b}$ ), dimeric associates (for $\mathbf{3} \mathbf{c}$ ), or the fixation of an acetone molecule in the hollow between two diaminocarbene complexes (for $\mathbf{3 d}$ ) in the solid state. The Hirshfeld surface analysis for the studied X-ray structures estimated the contributions of intermolecular chalcogen bonds

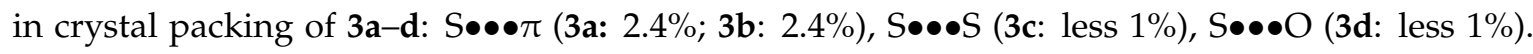
The additionally performed DFT calculations, followed by the topological analysis of the electron density distribution within the framework of Bader's theory (AIM method), confirm the presence

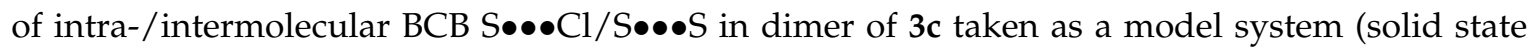
geometry). The AIM analysis demonstrates the presence of appropriate bond critical points for these interactions and defines their strength from 0.9 to $2.8 \mathrm{kcal} / \mathrm{mol}$ indicating their attractive nature.
\end{abstract}

Keywords: Chalcogen bonding; non-covalent interactions; Hirshfeld surface analysis; AIM analysis; diaminocarbene complexes

\section{Introduction}

The field of non-covalent interactions has grown explosively in the past decade. The hydrogen [1,2], halogen [3-10], chalcogen [11-24], pnictogen [25-31], tetrel [32] bonding, stacking [33-37], cation/anion- $\pi$ [38-42], and metallophilic interactions [43-45] play key roles in many chemical, physical, and biochemical processes, due to their ability to control structures and properties of associates and supramolecular systems.

Nowadays, one of the vigorously investigating types of such interactions is chalcogen bonding $(\mathrm{CB})$. CB is usually defined as non-covalent interactions between localized positive regions on 
a chalcogen atom in the extension of the covalent bonds ( $\sigma$-holes) and electron donor species serving as $C B$ acceptors [11-15,46-50]. Unlike halogens a chalcogen atom possess two $\sigma$-holes at the same time and is prone to the formation of bifurcated chalcogen bonding (BCB) (Figure 1) [51-57].
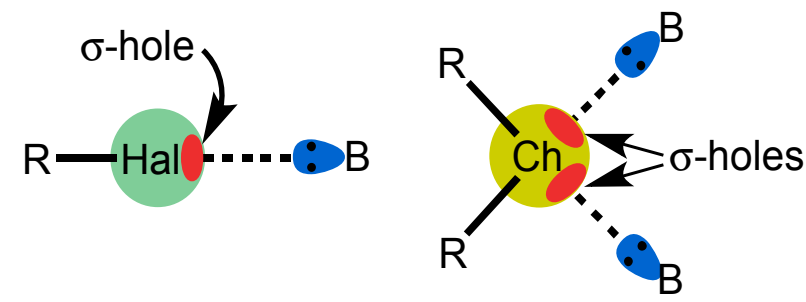

Figure 1. Patterns of halogen bonding $(\mathrm{XB})$ and bifurcated chalcogen bonding (BCB).

In the continuation of our projects focused on metal-mediated reactions of isocyanides $[15,58-68]$ and on non-covalent interactions $[15,58,69-77]$, we recently reported on the coupling between cis-[ $\left[\mathrm{PdCl}_{2}(\mathrm{CNXyl})_{2}\right]\left(\mathrm{Xyl}=2,6-\mathrm{Me}_{2} \mathrm{C}_{6} \mathrm{H}_{4}\right)$ and various thiazol- and thiadiazol-2-amines that leads to a mixture of two regioisomeric binuclear diaminocarbene complexes corresponding to kinetically (3a-d) or thermodynamically (4a-d) controlled regioisomers (Scheme 1). There is an equilibrium between these two species in $\mathrm{CHCl}_{3}$ solutions that depends on the energy difference between two types of

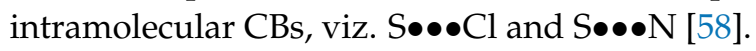

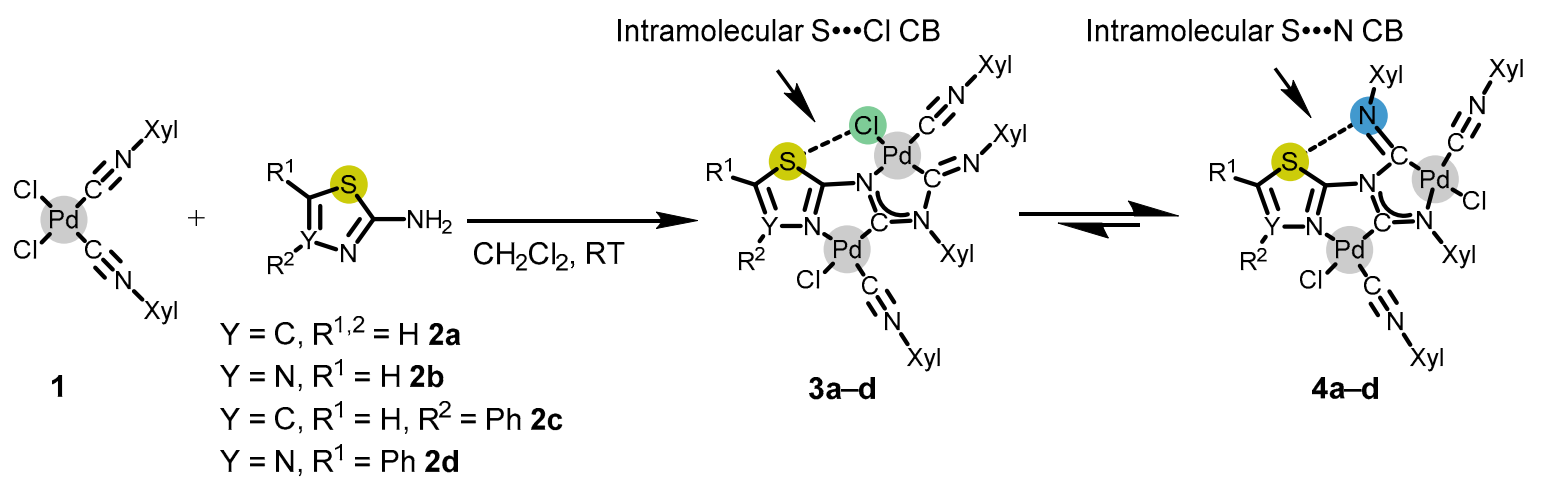

Scheme 1. Coupling of $c i s-\left[\mathrm{PdCl}_{2}(\mathrm{CNXyl})_{2}\right]$ with thiazol- and thiadiazol-2-amines.

In this work, we would like to focus on the ability of the sulfur atom in species $\mathbf{3 a - d}$ to participate not only in intramolecular $\mathrm{CB}$, but also in intermolecular contacts as a donor of bifurcated chalcogen bonding (BCB). We synthesized and characterized by single-crystal X-ray diffraction (XRD) binuclear (diaminocarbene) $\mathrm{Pd}^{\mathrm{II}}$ complex 3c, bearing 4-phenyl-thiazole moiety. Also we analyzed the earlier obtained single-crystal XRD data for binuclear diaminocarbene species with unsubstituted 1,3-thiazole (3a: CCDC code-EYOVIZ), unsubstituted 1,3,4-thiadiazole (3b: CCDC code-EYOWAS), and 5-phenyl-1,3,4-thiadiazole fragment (3d: CCDC code-EYOVOF). That allowed us to define the relationship between the nature and the position of the substituents in the ligands and the type of the non-covalent interaction. Additionally, we carried out the Hirshfeld surface analysis (for 3a-d) and DFT calculations followed by the topological analysis of the electron density distribution within the framework of Bader's theory (AIM method; for 3c) to study the nature and energies of these non-covalent interactions and determine their contributions in the crystal packing. These results are accordingly discussed in the sections that follow. 


\section{Materials and Methods}

\subsection{Materials and Instrumentation}

Solvents, $\mathrm{PdCl}_{2}$, 4-phenyl-1,3-thiazol-2-amine, and xylyl isocyanide were obtained from commercial sources and used as received. Complex cis-[ $\left.\mathrm{PdCl}_{2}(\mathrm{CNXyl})_{2}\right]$ was synthesized by the literature procedure [58]. Mass-spectra were obtained on a Bruker micrOTOF spectrometer (Billerica, Massachusetts, MA, USA) equipped with electrospray ionization (ESI) source; a mixture of $\mathrm{MeOH}$ and $\mathrm{CH}_{2} \mathrm{Cl}_{2}$ was used for samples dissolution. The instrument was operated at a positive ion mode using $\mathrm{m} / \mathrm{z}$ range of 50-3000. The capillary voltage of the ion source was set at $-4500 \mathrm{~V}$ and the capillary exit at 50-150 V. The nebulizer gas pressure was 0.4 bar and the drying gas flow $4.0 \mathrm{~L} / \mathrm{min}$. All NMR spectra were acquired on a Bruker Avance 400 spectrometer (Billerica, Massachusetts, MA, USA) in $\mathrm{CDCl}_{3}$ at ambient temperature.

\subsection{Synthesis and Characterization}

Complex 3c were synthesized by reported procedure [58]. A solution of 4-phenyl-1,3-thiazol-2amine $(12 \mathrm{mg}, 0.068 \mathrm{mmol})$ in $\mathrm{CH}_{2} \mathrm{Cl}_{2}(3 \mathrm{~mL})$ was added to solid cis-[ $\left.\mathrm{PdCl}_{2}(\mathrm{CNXyl})_{2}\right](20 \mathrm{mg}$, $0.045 \mathrm{mmol}$ ) placed in a 10-mL round-bottom flask. The reaction mixture was stirred in air at RT for $24 \mathrm{~h}$. The color of the reaction mixture gradually turned from pale yellow to intense lemon yellow and solid cis- $\left[\mathrm{PdCl}_{2}(\mathrm{CNXyl})_{2}\right]$ was dissolved. The formed solution was filtered from some insoluble material and evaporated to dryness. Then, the solid residue was redissolved in an acetone $(1.5 \mathrm{~mL}) / \mathrm{CH}_{2} \mathrm{Cl}_{2}$ $(2 \mathrm{~mL})$ mixture and left to evaporate at $20-25^{\circ} \mathrm{C}$ to ca. $1 \mathrm{~mL}$ till the crystalline product formation.

3c. Yield: $49 \%$ (11 mg). HRESI ${ }^{+}-\mathrm{MS}$ : calcd for $\mathrm{C}_{45} \mathrm{H}_{42} \mathrm{ClN}_{6} \mathrm{SPd}_{2}{ }^{+} 947.0949$, found $\mathrm{m} / \mathrm{z} 947.0973$ [M-Cl] ${ }^{+} .{ }^{1} \mathrm{H}$ NMR $(\delta, \mathrm{ppm}, \mathrm{J} / \mathrm{Hz}): 2.08\left(\mathrm{~s}, 6 \mathrm{H}, \mathrm{CH}_{3}, \mathrm{Xyl}\right), 2.22\left(\mathrm{~s}, 6 \mathrm{H}, \mathrm{CH}_{3}, \mathrm{Xyl}\right), 2.26\left(\mathrm{~s}, 6 \mathrm{H}, \mathrm{CH}_{3}, \mathrm{Xyl}\right)$, $2.48\left(\mathrm{~s}, 6 \mathrm{H}, \mathrm{CH}_{3}, \mathrm{Xyl}\right), 6.19(\mathrm{t}, 1 \mathrm{H}$, para- $\mathrm{H}, \mathrm{Xyl}, \mathrm{J}=7.5), 6.56(\mathrm{t}, 1 \mathrm{H}$, para- $\mathrm{H}, \mathrm{Xyl}, \mathrm{J}=7.6), 6.67(\mathrm{~d}, 2 \mathrm{H}$, meta-H, Xyl, J = 7.5), $6.71(\mathrm{~s}, 1 \mathrm{H}$, thiazole), $6.88(\mathrm{~d}, 2 \mathrm{H}$, meta-H, Xyl, J = 7.6), $6.98(\mathrm{~d}, 2 \mathrm{H}$, meta- $\mathrm{H}, \mathrm{Xyl}$, $\mathrm{J}=7.6), 7.01(\mathrm{~d}, 2 \mathrm{H}$, meta-H, $\mathrm{Xyl}, \mathrm{J}=7.3), 7.11-7.19(\mathrm{~m}, 2 \mathrm{H}$, para- $\mathrm{H}, \mathrm{Xyl}), 7.35-7.39(\mathrm{~m}, 3 \mathrm{H}$, meta- and para- $\mathrm{H}, \mathrm{Ph}) 7.47-7.52(\mathrm{~m}, 2 \mathrm{H}$, orto- $\mathrm{H}, \mathrm{Ph})$.

\subsection{X-ray Structure Determination}

Single crystal of $3 \mathrm{c}$ was grown from an acetone $/ \mathrm{CH}_{2} \mathrm{Cl}_{2}$ mixture. The crystal was measured at Agilent Technologies SuperNova diffractometer at a temperature of $100 \mathrm{~K}$ using monochromated $\mathrm{CuK} \alpha$ radiation (Yarnton, Oxfordshire, UK). The structures have been solved by the direct methods and refined by means of the SHELX program [78] incorporated in the OLEX2 program package [79]. The crystallographic data and some parameters of refinement are placed in Table 1. The carbon-bound $\mathrm{H}$ atoms were placed in calculated positions and were included in the refinement in the 'riding' model approximation, with Uiso(H) set to $1.5 \mathrm{Ueq}(\mathrm{C})$ and $\mathrm{C}-\mathrm{H} 0.96 \AA$ for $\mathrm{CH}_{3}$ groups and with Uiso(H) set to $1.2 \mathrm{Ueq}(\mathrm{C}), \mathrm{C}-\mathrm{H} 0.93 \AA$ for $\mathrm{CH}$ groups. Empirical absorption correction was applied in CrysAlisPro program complex using spherical harmonics, implemented in SCALE3 ABSPACK scaling algorithm [80]. The unit cell of $3 c$ also contains disordered dichloromethane molecules, which have been treated as a diffuse contribution to the overall scattering without specific atom positions by SQUEEZE/PLATON [81]. Supplementary crystallographic data for this paper have been deposited at Cambridge Crystallographic Data Centre (1815713) and can be obtained free of charge via www.ccdc.cam.ac.uk/data_request/cif. 
Table 1. Crystal data and structure refinement for 3c.

\begin{tabular}{|c|c|}
\hline Empirical Formula & $\mathrm{C}_{45} \mathrm{H}_{42} \mathrm{~N}_{6} \mathrm{SCl}_{2} \mathrm{Pd}_{2}$ \\
\hline Formula weight & 982.61 \\
\hline Temperature/K & $100(2)$ \\
\hline Crystal system & triclinic \\
\hline Space group & $P-1$ \\
\hline $\mathrm{a} / \AA$ & $8.2666(4)$ \\
\hline $\mathrm{b} / \AA$ & $14.3733(8)$ \\
\hline $\mathrm{c} / \AA$ & $19.2538(9)$ \\
\hline$\alpha /^{\circ}$ & $99.238(4)$ \\
\hline$\beta /{ }^{\circ}$ & $97.705(4)$ \\
\hline$\gamma /{ }^{\circ}$ & $97.182(4)$ \\
\hline Volume $/ \AA^{3}$ & $2212.40(19)$ \\
\hline $\mathrm{Z}$ & 2 \\
\hline$\rho_{\text {calc }} \mathrm{g} / \mathrm{cm}^{3}$ & 1.473 \\
\hline$\mu / \mathrm{mm}^{-1}$ & 8.390 \\
\hline $\mathrm{F}(000)$ & 992.0 \\
\hline Crystal size $/ \mathrm{mm}^{3}$ & $0.22 \times 0.16 \times 0.09$ \\
\hline Radiation & $\mathrm{CuK} \alpha(\lambda=1.54184)$ \\
\hline $2 \Theta$ range for data collection $/{ }^{\circ}$ & $6.3-139.9$ \\
\hline Index ranges & $-10 \leq \mathrm{h} \leq 10,-17 \leq \mathrm{k} \leq 17,-19 \leq 1 \leq 23$ \\
\hline Reflections collected & 24325 \\
\hline Independent reflections & $8247\left[R_{\text {int }}=0.0764, R_{\text {sigma }}=0.0679\right]$ \\
\hline Data/restraints/parameters & $8247 / 0 / 495$ \\
\hline Goodness-of-fit on $\mathrm{F}^{2}$ & 1.019 \\
\hline Final $\mathrm{R}$ indexes $[\mathrm{I}>=2 \sigma(\mathrm{I})]$ & $\mathrm{R}_{1}=0.0523, \mathrm{w} \mathrm{R}_{2}=0.1422$ \\
\hline Final $\mathrm{R}$ indexes [all data] & $\mathrm{R}_{1}=0.0623, \mathrm{w} \mathrm{R}_{2}=0.1592$ \\
\hline Largest diff. peak/hole/e $\AA^{-3}$ & $2.25 /-1.64$ \\
\hline
\end{tabular}

\subsection{Details of Hirshfeld Surface Analysis}

The Hirshfeld molecular surfaces were generated by CrystalExplorer 3.1 program [82,83]. The normalized contact distances, $\mathrm{d}_{\text {norm }}$ [84], based on Bondi's van der Waals radii [85], were mapped into the Hirshfeld surface. In the color scale, negative values of dnorm are visualized by the red color indicating contacts shorter than the sum of van der Waals radii. The white color denotes intermolecular distances that are close to van der Waals contacts with $d_{\text {norm }}$ equal to zero. In turn, contacts longer than the sum of van der Waals radii with positive $d_{\text {norm }}$ values are colored with blue.

\subsection{Computational Details.}

The single point DFT calculations with relativistic core Hamiltonian $[86,87]$ based on the experimental X-ray data for 3c have been carried out at the M06/DZP-DKH level of theory in Gaussian-09 [88] program package. The topological analysis of the electron density distribution with the help of the "atoms in molecules" (AIM) method developed by R. Bader [89] has been performed by using the Multiwfn program [90]. The Wiberg bond indices were computed by using the Natural Bond Orbital (NBO) partitioning scheme [91].

\section{Results and Discussion}

\subsection{Synthesis and Crystallization}

In accordance with our recently reported procedure [58], binuclear (diaminocarbene)Pd ${ }^{\mathrm{II}}$ complex 3c was synthesized by coupling of cis-[ $\left[\mathrm{PdCl}_{2}(\mathrm{CNXyl})_{2}\right]\left(\mathrm{Xyl}=\mathrm{Me}_{2} \mathrm{C}_{6} \mathrm{H}_{3}\right)$ with 4-phenyl-1,3-thiazol-2-amine in molar ratio 2:3 at $\mathrm{RT}$ in $\mathrm{CH}_{2} \mathrm{Cl}_{2}$ (Scheme 1) followed by purification of the formed species by fractional crystallization from an acetone $/ \mathrm{CH}_{2} \mathrm{Cl}_{2}$ mixture. Crystals of $3 \mathbf{c}$ for XRD were grown also from an acetone $/ \mathrm{CH}_{2} \mathrm{Cl}_{2}$ mixture. The complex was characterized by 
HRESI $^{+}$-MS, ${ }^{1} \mathrm{H}$ NMR spectroscopy (Section 2.2), and its structure was elucidated by single-crystal X-ray diffraction (Section 3.2.2).

\subsection{Non-Covalent Interactions in the Crystal Structures of $3 a-d$}

\subsubsection{Recognition of $\mathrm{S} \bullet \bullet \bullet \mathrm{Cl} / \mathrm{S} \bullet \bullet \bullet \pi \mathrm{BCBs}$ in $\mathbf{3 a}, \mathbf{b}$}

In both the structures of $\mathbf{3 a}$ (EYOVIZ) and $\mathbf{3 b}$ (EYOWAS) with unsubstituted thiazole/thiadiazole moieties, intra-/intermolecular BCB S $\bullet \bullet \mathrm{Cl} / \mathrm{S} \bullet \bullet \bullet \pi_{\mathrm{Xyl}}$ are present (Figure 2). Remarkably the change of heterocyclic system (from thiazole in $\mathbf{3} \mathbf{a}$ to thiadiazole to $\mathbf{3 b}$ ) does not affect the pattern of non-covalent interactions and structures of $\mathbf{3} \mathbf{a}$ and $\mathbf{3} \mathbf{b}$ are isomorphic. The corresponding distances $\mathrm{S} \bullet \bullet \bullet C l$ and the distances between the sulfur and both the center of $\pi$-system of Xyl ring (Xyl center) and the closest $C$ atom in this $\pi$-system are less than the sum of Rowland's [92] and Bondi's [85] vdW radii of these atoms, whereas the corresponding angles $\mathrm{C}-\mathrm{S} \bullet \bullet \bullet \mathrm{Cl}$ and $\mathrm{C}-\mathrm{S} \bullet \bullet \bullet X y l_{\text {center }}$ are close to $180^{\circ}$ (Table 2) and these contacts could be defined as CBs $[93,94]$.
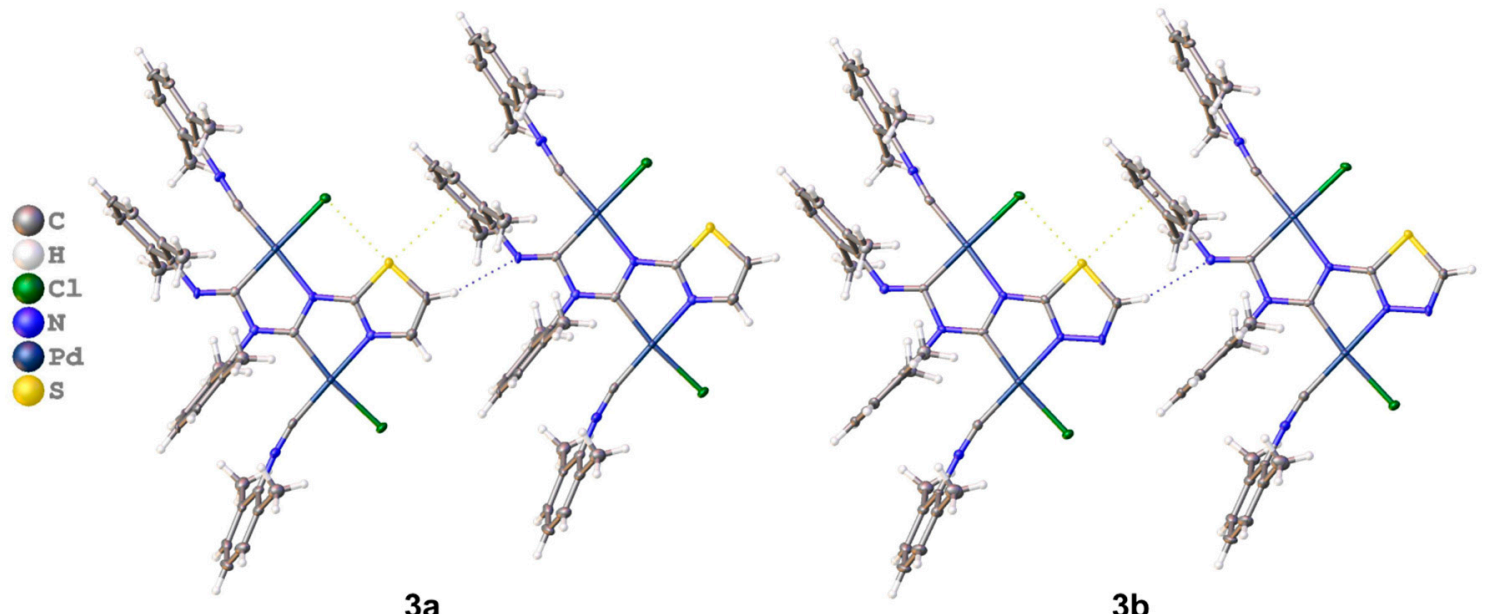

Figure 2. Views of $\mathbf{3 a}$ and $\mathbf{3 b}$. Thermal ellipsoids are drawn at the 50\% probability level. Dotted lines indicate the $\mathrm{S} \bullet \bullet \bullet \mathrm{Cl}, \mathrm{S} \bullet \bullet \bullet \pi$, and $\mathrm{H} \bullet \bullet \bullet \mathrm{N}$ contacts.

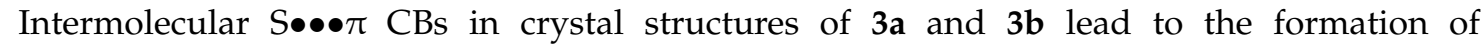
one-dimensional (1D) chains (Figure 3). These interactions in both structures are also supported by the intermolecular $\mathrm{C}-\mathrm{H} \bullet \bullet \bullet \mathrm{N}$ hydrogen bonds (HBs) and their parameters (Table 2) are consistent with the IUPAC criterion [95].

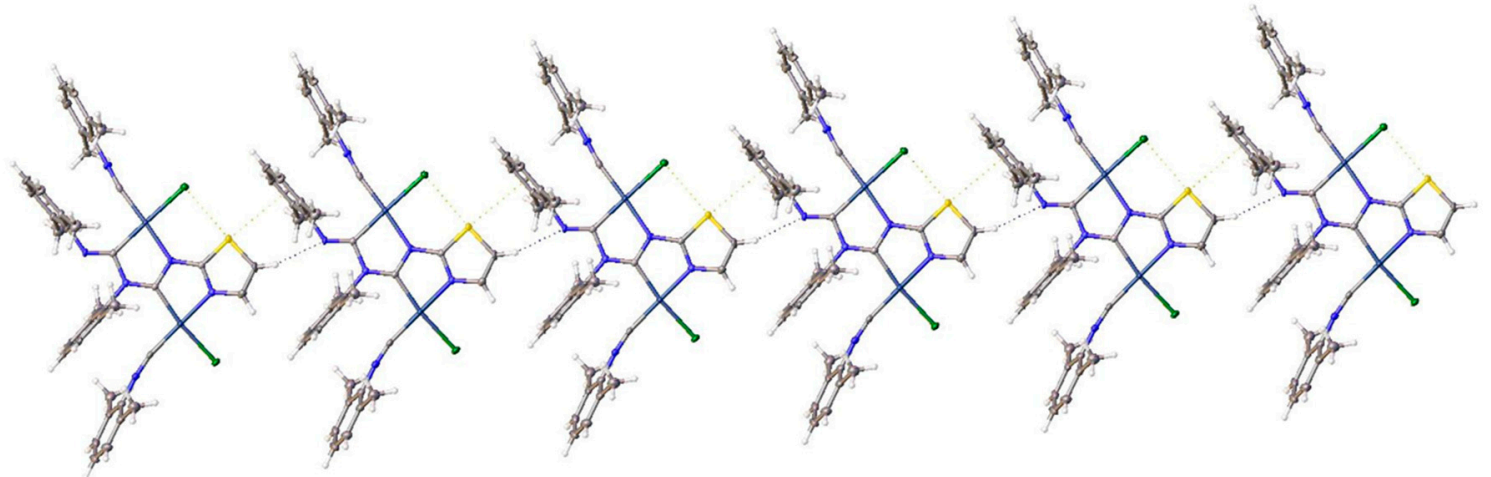

Figure 3. Fragment of one-dimensional (1D) chain of 3a. Thermal ellipsoids are drawn at the $50 \%$ probability level. Dotted lines indicate the $\mathrm{S} \cdots \mathrm{Cl}, \mathrm{S} \cdots \pi$, and $\mathrm{H} \cdots \mathrm{N}$ contacts. 
Table 2. Distances $(\AA)$ and angles $\left(^{\circ}\right)$ for chalcogen bonding $(\mathrm{CBs})$ and hydrogen bonds $(\mathrm{HBs})$ in the structures of $3 \mathbf{a}$ and $3 \mathbf{b}$.

\begin{tabular}{|c|c|c|c|c|c|}
\hline Contact & Parameter & $3 a$ & $3 b$ & Rowland wdV [92] & Bondi wdV [85] \\
\hline \multirow{3}{*}{ Intramolecular CB } & $d(S \bullet \bullet \bullet C l)$ & $3.097(2)$ & $3.0927(9)$ & \multirow[t]{2}{*}{3.57} & \multirow[t]{2}{*}{3.55} \\
\hline & $\angle(\mathrm{Y}-\mathrm{S} \bullet \bullet \bullet C l)$ & $172.0(3)$ & $172.79(12)$ & & \\
\hline & $d(S \bullet \bullet \bullet C)$ & $3.445(7)$ & $3.425(3)$ & \multirow[t]{4}{*}{3.58} & \multirow[t]{4}{*}{3.50} \\
\hline \multirow{3}{*}{ Intermolecular CB } & $d\left(S \bullet \bullet \bullet X l_{c e n t r}\right)$ & $3.351(3)$ & $3.2906(13)$ & & \\
\hline & $\angle(Y-S \bullet \bullet \bullet X y l)$ & $172.0(3)$ & $172.79(12)$ & & \\
\hline & $\angle\left(\mathrm{S} \bullet \bullet X_{y} l_{\text {plane }}\right)$ & $88.6(3)$ & $91.45(11)$ & & \\
\hline \multirow{3}{*}{ Intermolecular HB } & $d(H \bullet \bullet \bullet N)$ & $2.51(5)$ & $2.50(5)$ & 2.74 & 2.75 \\
\hline & $d(C \bullet \bullet \bullet N)$ & $3.361(9)$ & $3.349(4)$ & \multirow[t]{2}{*}{3.41} & \multirow[t]{2}{*}{3.25} \\
\hline & $\angle(\mathrm{C}-\mathrm{H} \bullet \bullet \bullet N)$ & 151(1) & 151(1) & & \\
\hline
\end{tabular}

\subsubsection{Recognition of $\mathrm{S} \bullet \bullet \bullet C l / S \bullet \bullet \bullet S B C B$ in $3 c$}

The sulfur atom in $3 c$ possesses one intramolecular $\mathrm{CB}$ with the $\mathrm{Pd}^{\mathrm{II}}$-bound chloride (as in the previous cases) and one intermolecular $\mathrm{CB}$ with the symmetrically located $\mathrm{S}$ atom in the neighboring molecule (Type I [96]; Figure 4). In contrast to 3a,b steric hindrance of the bulky phenyl substituent in the $4^{\text {th }}$ position of the thiazole ring prevents formation of $S \bullet \bullet \bullet \pi_{\mathrm{Xyl}} \mathrm{CB}$ and leads to the formation

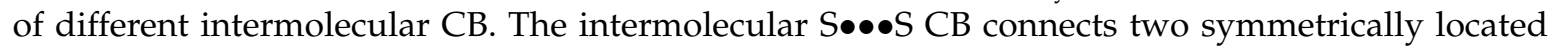
molecules of $3 c$ providing the dimeric structure in the solid state. The distances between the $S$ and the $\mathrm{Cl}(3.1419(18) \AA)$ and between two S atoms (3.459(2) $\AA$ ) are less than the sum of their Rowland's [92]

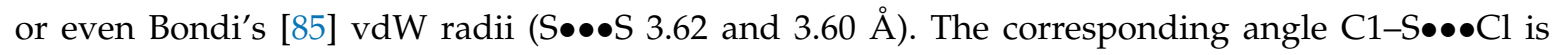

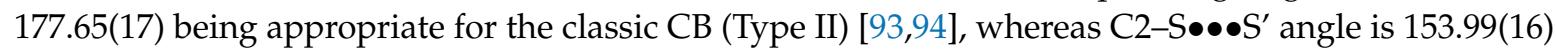
in the case of both symmetrically located molecules of $3 c$ revealing that it is Type I interaction [96].

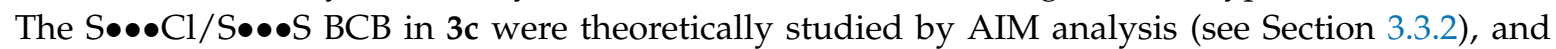

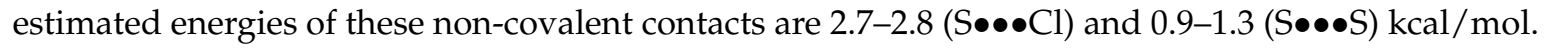

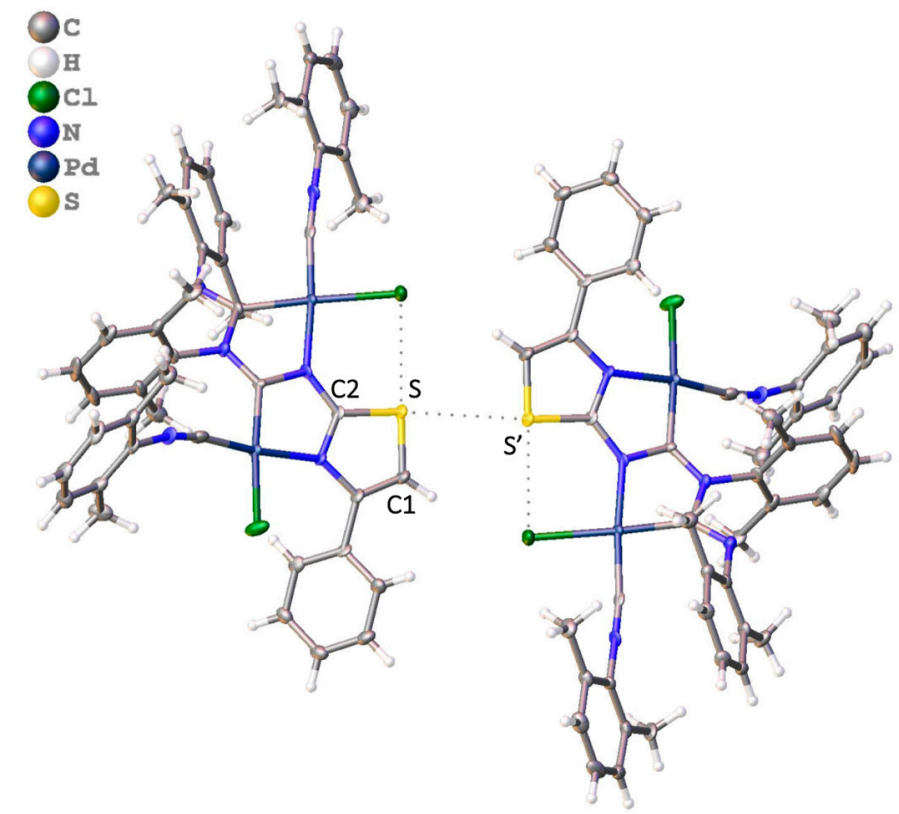

Figure 4. View of dimer of 3c. Thermal ellipsoids are drawn at the $50 \%$ probability level. Dotted lines indicate the $\mathrm{S} \bullet \bullet \bullet \mathrm{Cl}$ and $\mathrm{S} \bullet \bullet \bullet S$ contacts.

\subsubsection{Recognition of $\mathrm{S} \bullet \bullet \bullet C l / S \bullet \bullet \bullet \mathrm{OBCB}$ in $\mathbf{3 d}$}

Introduction of the Ph-group in the $5^{\text {th }}$ position of the thiadiazole fragment in case of $3 \mathbf{d}$ (EYOVOF)

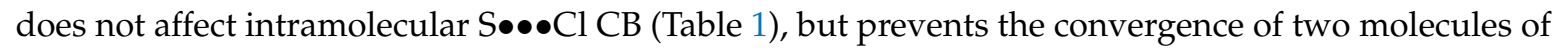


$3 \mathbf{d}$ with formation of intermolecular CBs between them (unlike above discussed structures). It leads to formation of hollows in the crystal structure between symmetrically located moieties of $\mathbf{3 d}$ in which solvated species can be placed and fixed by non-covalent interactions. In EYOVOF structure, two molecules of $\mathbf{3 d}$ co-crystallized with one molecule of acetone placed in the hollow between the complexes. This acetone molecule is disordered and exists in two positions with 0.5 occupancy each (Figure 5). The solvated acetone in each position is bonded by simultaneous $\mathrm{CB}$ and $\mathrm{HB}$ with the closest moiety of the complex forming six-membered cycle. The distance between the $\mathrm{O}$ and $\mathrm{H}(2.46(5) \AA)$ is less than the sum of their Rowland's [92] (2.68 $\AA$ ) whereas the distance between the $\mathrm{O}$ and $\mathrm{C}(3.373(6) \AA)$

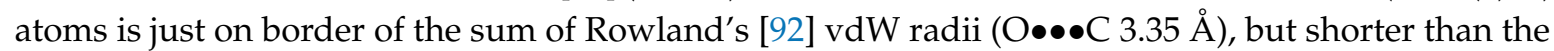
sum of Allinger's vdW radii $(\mathrm{O} \bullet \bullet \bullet C$ 3 $3.64 \AA$ [97]), and the corresponding angle $\mathrm{C}-\mathrm{H} \bullet \bullet \bullet \mathrm{O}$ is close to

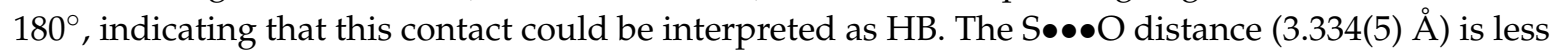
than the sum of their Rowland's [92] (3.39 $\AA$ ) and on the border of Bondi's [85] vdW radii (3.32 $\AA$ ) and the angle $\mathrm{C}-\mathrm{S} \bullet \bullet \bullet \mathrm{O}$ is in range $150^{\circ}-180^{\circ}$ so this contact could be defined as CB $[93,94]$.

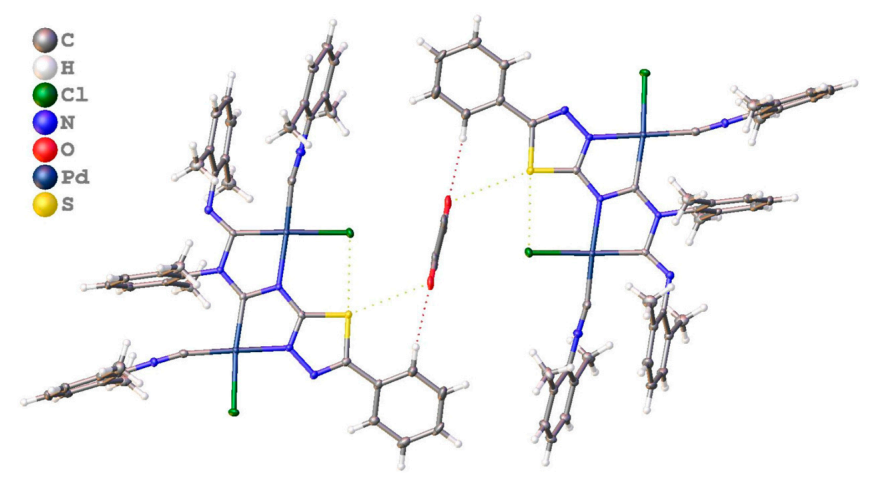

Figure 5. View of solvate of $\mathbf{3 d}$ with acetone. Thermal ellipsoids are drawn at the $50 \%$ probability level. Dotted lines indicate the $\mathrm{S} \bullet \bullet \bullet \mathrm{Cl}, \mathrm{S} \bullet \bullet \bullet \mathrm{O}$, and $\mathrm{H} \bullet \bullet \bullet \mathrm{O}$ contacts.

Additionally, there is the contact between the $\mathrm{C}$ atom of the $\mathrm{C}=\mathrm{O}$ group in acetone and the Pd-bound chloride (Figure 6). The distances between the $\mathrm{C}$ and $\mathrm{Cl}$ atoms (3.307(7) $\AA$ ) are substantially less than the sums of Rowland's [92], or even Bondi's [85], vdW radii (3.53 and 3.45 $\AA$ ). In this case the acyl $C$ atom should acts as an electron density acceptor due to the $\pi$-hole on it [32,98-100], whereas the lone pair of the chloride ligand is an electron density donor.

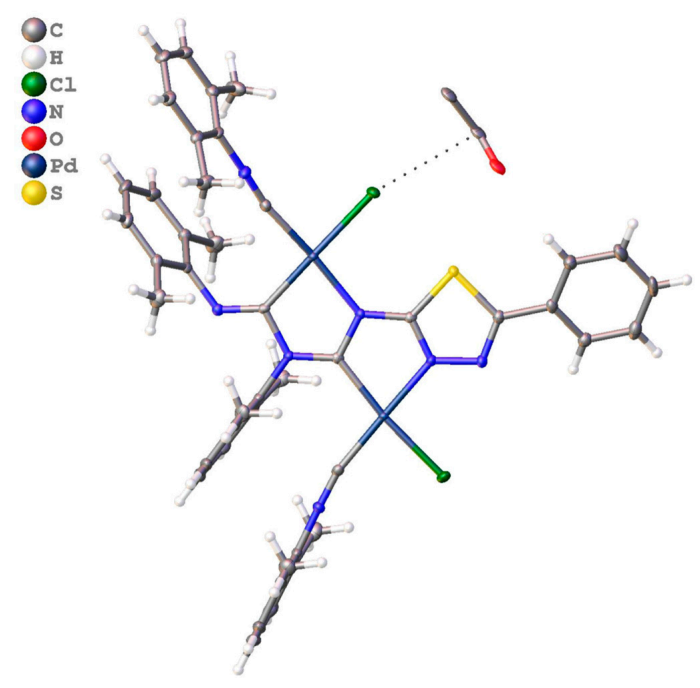

Figure 6. View of solvate of $3 \mathbf{d}$ with acetone. Thermal ellipsoids are drawn at the $50 \%$ probability level. Dotted lines indicate the $\mathrm{C} \cdots \mathrm{Cl}$ contact. 
3.3. Theoretical Consideration of Intra-/Intermolecular Bifurcated Chalcogen Bonding in Thiazole/Thiadiazole Derived Binuclear (Diaminocarbene)Pdii Complexes

\subsubsection{Hirshfeld Surface Analysis for the X-ray Structures of 3a-d}

The molecular Hirshfeld surface represents an area where molecules come into contacts, and its analysis gives the possibility of an additional insight into the nature of intermolecular interactions in the crystal state. We carried out the Hirshfeld surface analysis for the X-ray structures of $\mathbf{3 a}-\mathbf{d}$ to understand what kind of intermolecular contacts gives the largest contributions in crystal packing (Table 3).

Table 3. Results of the Hirshfeld surface analysis for the X-ray structures of 3a-d.

\begin{tabular}{|c|c|}
\hline X-ray structure & Contributions of Different Intermolecular Contacts to the Molecular Hirshfeld Surface * \\
\hline $3 a$ & $\mathrm{H}-\mathrm{H} 52.8 \%, \mathrm{Cl}-\mathrm{H} 15.3 \%, \mathrm{C}-\mathrm{H} 13.8 \%, \mathrm{~N}-\mathrm{H}$ 5.7\%, Pd-H 3.6\%, S-H 3.4\%, C-C 2.5\%, S-C $2.4 \%$ \\
\hline $3 b$ & H-H 49.3\%, Cl-H 16.0\%, C-H 11.9\%, N-H 9.2\%, Pd-H 3.7\%, S-H 3.3\%, C-C 2.6\%, S-C 2.5\%, N-C 1.1\% \\
\hline $3 c$ & H-H 53.1\%, C-H 20.4\%, Cl-H 11.3\%, N-H 2.9\%, S-H 2.2\%, Pd-H 2.1\%, C-C $1.2 \%$ \\
\hline $3 d$ & $\begin{array}{l}\mathrm{H}-\mathrm{H} 45.9 \%, \mathrm{C}-\mathrm{H} 23.9 \%, \mathrm{Cl}-\mathrm{H} 11.9 \%, \mathrm{~N}-\mathrm{H} \text { 6.2\%, Pd-H 3.2\%, S-H } 2.9 \%, \mathrm{O}-\mathrm{H} 2.6 \%, \mathrm{C}-\mathrm{C} 1.9 \%, \mathrm{Cl}-\mathrm{C} 1.0 \% \text {, } \\
\text { * The contributions of all other intermolecular contacts do not exceed 1\%. }\end{array}$ \\
\hline
\end{tabular}

For the visualization, we have used a mapping of the normalized contact distance $\left(\mathrm{d}_{\text {norm }}\right)$; its negative value enables identification of molecular regions of substantial importance for detection of short contacts. The Figure 7 depicts the Hirshfeld surfaces for $\mathbf{3 b}-\mathbf{d}$. In these Hirshfeld surfaces, the regions of shortest intermolecular contacts visualized by red circle areas.
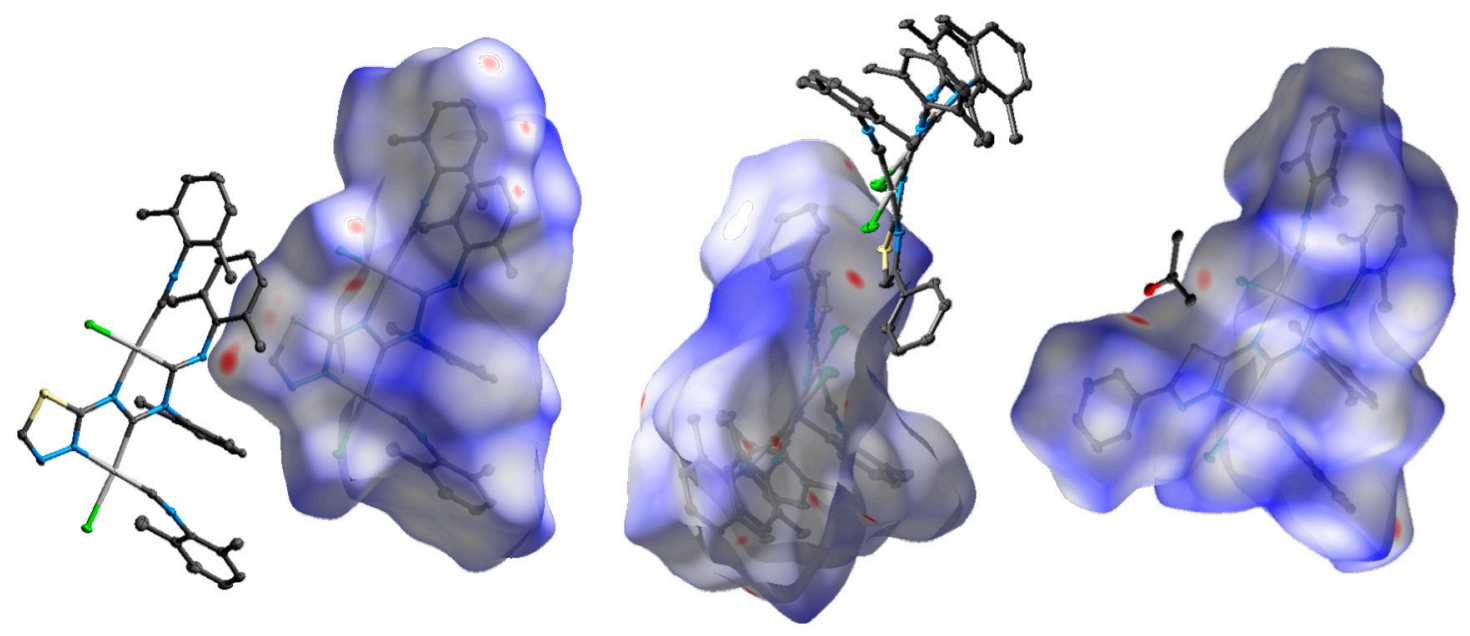

Figure 7. Hirshfeld surfaces for $\mathbf{3 b}$ (left), dimer of $\mathbf{3 c}$ (middle), solvate of $\mathbf{3 d}$ with acetone (right). Thermal ellipsoids are drawn at the $50 \%$ probability level; all of the hydrogen atoms are omitted for clarity.

The Hirshfeld surface analysis for the X-ray structures of 3a-d reveals that in all cases crystal packing is determined primarily by intermolecular contacts $\mathrm{H}-\mathrm{H}, \mathrm{Cl}-\mathrm{H}$, and $\mathrm{C}-\mathrm{H}$ and contributions of

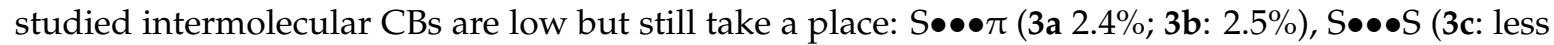

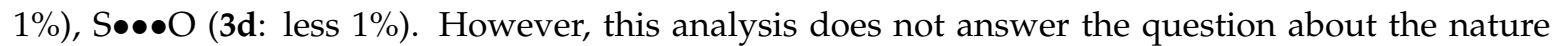
(attractive or repulsive) and energies of these contacts, and, therefore, the DFT calculations should be further performed.

\subsubsection{The QTAIM and NBO Analyses of Intra-/Intermolecular Bifurcated Chalcogen Bonding}

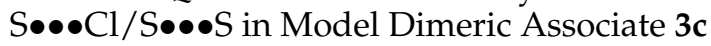

In order to confirm or disprove the hypothesis on the existence of intra-/intermolecular bifurcated chalcogen bonding (BCB) in the studied species we carried out DFT calculations and performed 
topological analysis of the electron density distribution within the framework of Bader's theory (AIM

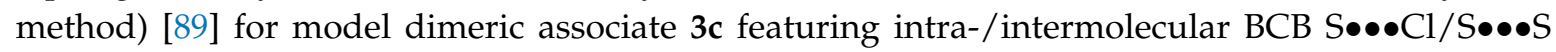
to quantify energies of appropriate contacts from theoretical viewpoint. This model dimeric associate was obtained from the corresponding X-ray structure. Results are summarized in Table 4, the contour line diagram of the Laplacian distribution $\nabla^{2} \rho(\mathbf{r})$, bond paths, and selected zero-flux

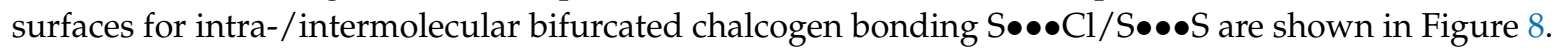
To visualize studied non-covalent interactions, reduced density gradient (RDG) analysis [101] was

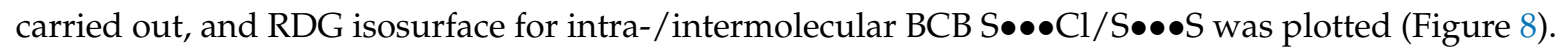
The Poincare-Hopf relationship was satisfied, and all of the critical points have been found.

Table 4. Values of the density of all electrons $-\rho(\mathbf{r})$, Laplacian of electron density $-\nabla^{2} \rho(\mathbf{r})$, energy density $-\mathrm{H}_{\mathrm{b}}$, potential energy density $-\mathrm{V}(\mathbf{r})$, and Lagrangian kinetic energy $-\mathrm{G}(\mathbf{r})$ (Hartree) at the bond critical points, corresponding to intra-/intermolecular bifurcated chalcogen bonding $\mathrm{S} \bullet \bullet \bullet \mathrm{Cl} / \mathrm{S} \bullet \bullet \bullet$ in model dimeric associate 3c, Wiberg bond indices (WI), as well as energies for appropriate contacts $\mathrm{E}_{\text {int }}$ $(\mathrm{kcal} / \mathrm{mol})$, defined by two approaches.

\begin{tabular}{ccccccccc}
\hline Contact & $\boldsymbol{\rho}(\mathbf{r})$ & $\boldsymbol{\nabla}^{\mathbf{2}} \boldsymbol{\rho}(\mathbf{r})$ & $\mathbf{H}_{\mathbf{b}}$ & $\mathbf{V}(\mathbf{r})$ & $\mathbf{G}(\mathbf{r})$ & $\mathbf{E}_{\text {int }}{ }^{\mathbf{a}}$ & $\mathbf{E}_{\text {int }} \mathbf{b}$ & WI \\
\hline$S \bullet \bullet \bullet C l$ & 0.015 & 0.049 & 0.002 & -0.009 & 0.010 & 2.8 & 2.7 & 0.02 \\
$S \bullet \bullet \bullet S$ & 0.007 & 0.024 & 0.001 & -0.003 & 0.005 & 0.9 & 1.3 & 0.01 \\
\hline \multicolumn{8}{c}{${ }^{a} E_{\text {int }}=-\mathrm{V}(\mathrm{r}) / 2{ }^{\mathrm{b}} \mathrm{E}_{\text {int }}=0.429 \mathrm{G}(\mathrm{r})}$. \\
\end{tabular}
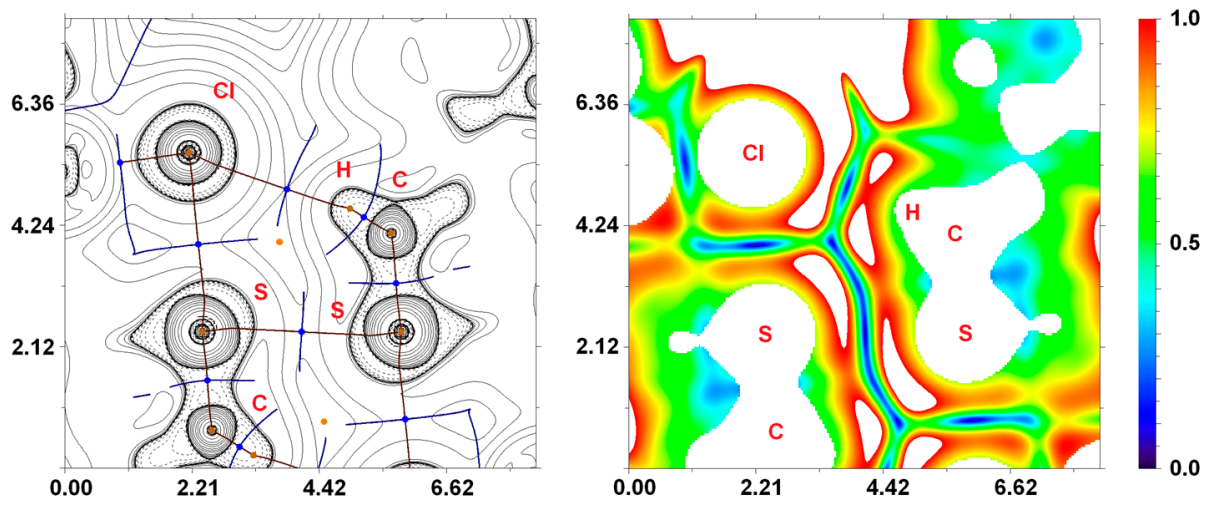

Figure 8. Contour line diagram of the Laplacian distribution $\nabla^{2} \rho(\mathbf{r})$, bond paths and selected zero-flux surfaces (left) and RDG isosurface (right) referring to the intra-/intermolecular bifurcated chalcogen bonding S $\bullet \bullet C l / S \bullet \bullet \bullet S$ in model dimeric associate 3c. Bond critical points are shown in blue, nuclear critical points- in pale brown, ring critical points-in orange. Length units- $\AA$, RDG isosurface values are given in Hartree.

The AIM analysis demonstrates the presence of appropriate bond critical points (BCPs) for the

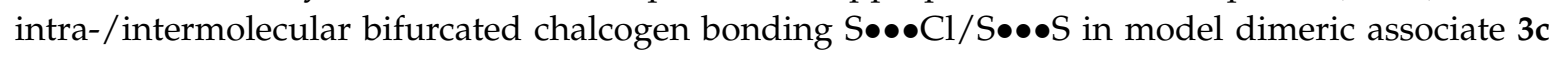
(Table 4). The low magnitude of the electron density (0.007-0.015 Hartree), positive values of the Laplacian (0.024-0.049 Hartree), and close to zero positive energy density (0.001-0.002 Hartree) in these $\mathrm{BCPs}$ are typical for non-covalent interactions. We have defined energies for these contacts according to the procedures proposed by Espinosa et al. [102] and Vener et al. [103] (Table 4). The strength of intramolecular $\mathrm{S} \bullet \bullet \bullet \mathrm{Cl} \mathrm{CB}$ is in the range of $2.8-2.9 \mathrm{kcal} / \mathrm{mol}$, which is comparable with contacts in previously studied thiazole/thiadiazole derived binuclear (diaminocarbene) $\mathrm{Pd}^{\mathrm{II}}$

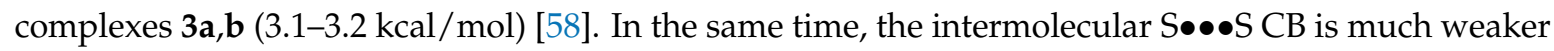
$(0.9-1.3 \mathrm{kcal} / \mathrm{mol})$ than intramolecular contact in 3c, but its energy is comparable with I type CB contacts in the $\mathrm{X}_{2} \mathrm{C}=\mathrm{S} \bullet \bullet \bullet \mathrm{S}=\mathrm{CX}_{2}(\mathrm{X}=\mathrm{H}, \mathrm{Cl}, \mathrm{F})$ systems $(0.7-1.1 \mathrm{kcal} / \mathrm{mol})$ [96]. The balance between the Lagrangian kinetic energy $\mathrm{G}(\mathbf{r})$ and potential energy density $\mathrm{V}(\mathrm{r})$ at the $\mathrm{BCPs}$ reveals the nature of 
these interactions, if the ratio $-G(\mathbf{r}) / V(\mathbf{r})>1$ is satisfied, than the nature of appropriate interaction is purely non-covalent, in case the $-\mathrm{G}(\mathbf{r}) / \mathrm{V}(\mathbf{r})<1$ some covalent component takes place [104]. Based on this criterion one can state that a covalent contribution in both discussed above contacts is absent, and negligible values of Wiberg bond indices additionally confirm this observation.

\section{Conclusions}

In summary, we have synthesized and characterized by single-crystal XRD binuclear (diaminocarbene) $\mathrm{Pd}^{\mathrm{II}}$ complex $3 \mathrm{c}$ bearing 4-phenyl-1,3-thiazole moiety, and, additionally, analyzed the CCDC data for three relevant earlier obtained binuclear diaminocarbene species with unsubstituted and 5-phenyl-substituted thiazole/thiadiazole moieties (3a: EYOVIZ; 3b: EYOWAS; 3d: EYOVOF). Inspection of the single-crystal XRD data for $3 \mathbf{a}-\mathbf{d}$ reveals that the structure of all these species exhibits the intra-/intermolecular bifurcated chalcogen bonding (BCB) (Section 3.2). The XRD data for $\mathbf{3 a}, \mathbf{b}$ (EYOVIZ, EYOWAS) indicate the presence of the intramolecular S$\bullet \bullet \cdot C l$ CB in both cases, and, additionally, of the intermolecular contacts of $\sigma$-hole on the $S$ atom with the Xyl ring $\pi$-system of the neighboring molecule (Section 3.2.1). In the same time, introduction of the phenyl substituent in the $4^{\text {th }}$ and $5^{\text {th }}$ positions of the cyclic fragment does not affect intramolecular $\mathrm{S} \bullet \bullet \bullet C l C B$, but leads to dramatic changes of intermolecular CB's type. Substitution of the thiazole fragment in the $4^{\text {th }}$ position (3c) leads to change of the intermolecular CB's type from the $S \bullet \bullet \bullet \pi$ CB to the symmetrical

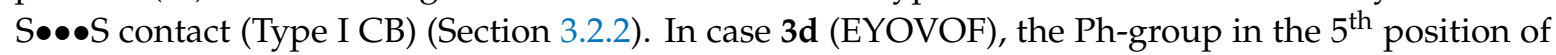
the thiadiazole fragment prevents the formation of any intramolecular CBs with the neighboring

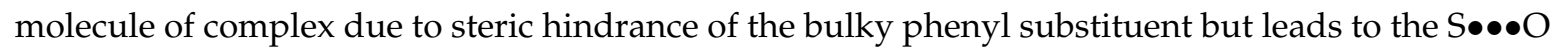
CB with co-crystallized molecule of acetone (Section 3.2.3). The presence of the intermolecular CB leads to formation of $1 \mathrm{D}$ polymeric chains (for $\mathbf{3 a}, \mathbf{b}$ ), dimeric associates (for $\mathbf{3} \mathbf{c}$ ), or fixation of the acetone molecules in the hollows between two diaminocarbene complexes (for $\mathbf{3 d}$ ) in the solid state. The preformed Hirshfeld surface analysis for the studied X-ray structures estimated the contributions

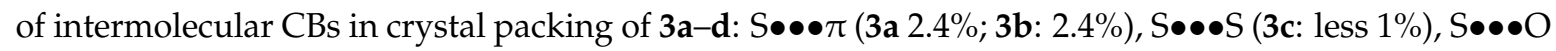
(3d: less 1\%) (Section 3.3.1).

The additionally performed DFT calculations, followed by the topological analysis of the electron density distribution within the framework of Bader's theory (AIM method), confirm the presence of

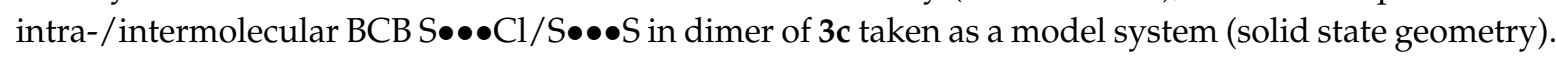
The AIM analysis demonstrates the presence of appropriate bond critical points for these interactions and defines their strength from 0.9 to $2.8 \mathrm{kcal} / \mathrm{mol}$, indicating their attractive nature (Section 3.3.2.).

Thus, the obtained data indicates that the sulfur atoms in these binuclear diaminocarbene species are able to act as donors of the intra/intermolecular bifurcated chalcogen bonding (BCB) and its type depends on the nature and the position of the substituents in the heterocyclic fragment. These results are useful for understanding the relationship between the molecular structure and the crystal packing of systems with CBs donors and offer new opportunities in the crystal design of functional materials.

Acknowledgments: Support of the synthetic work and compound characterization from the Russian Science Foundation (grant 14-43-00017P) is gratefully acknowledged. Theoretical part of this work was conducted under the Russian Foundation for Basic Research project (16-33-60063). Physicochemical studies were performed at the Center for Magnetic Resonance, Center for X-ray Diffraction Studies, and Center for Chemical Analysis and Materials Research (all belong to Saint Petersburg State University).

Author Contributions: Alexander S. Mikherdov performed synthetic work and crystallization and analyzed data. Andrey A. Zolotarev performed X-ray experiment and structure determinations. Alexander S. Novikov, performed the Hirshfeld surface analysis and AIM analysis. Vadim P. Boyarskiy and Mikhail A. Kinzhalov supervised the research. All author made equal contributions in writing of manuscript.

Conflicts of Interest: The authors declare no conflict of interest. 


\section{References}

1. Kollman, P.A.; Allen, L.C. Theory of the Hydrogen Bond. Chem. Rev. 1972, 72, 283-303. [CrossRef]

2. Grabowski, S.J. What Is the Covalency of Hydrogen Bonding? Chem. Rev. 2011, 111, 2597-2625. [CrossRef] [PubMed]

3. Gilday, L.C.; Robinson, S.W.; Barendt, T.A.; Langton, M.J.; Mullaney, B.R.; Beer, P.D. Halogen Bonding in Supramolecular Chemistry. Chem. Rev. 2015, 115, 7118-7195. [CrossRef] [PubMed]

4. Cavallo, G.; Metrangolo, P.; Milani, R.; Pilati, T.; Priimagi, A.; Resnati, G.; Terraneo, G. The Halogen Bond. Chem. Rev. 2016, 116, 2478-2601. [CrossRef] [PubMed]

5. Politzer, P.; Lane, P.; Concha, M.C.; Ma, Y.G.; Murray, J.S. An overview of halogen bonding. J. Mol. Model. 2007, 13, 305-311. [CrossRef] [PubMed]

6. Alkorta, I.; Sanchez-Sanz, G.; Elguero, J. Linear Free Energy Relationships in Halogen Bonds. CrystEngComm 2013, 15, 3178-3186. [CrossRef]

7. Politzer, P.; Riley, K.E.; Bulat, F.A.; Murray, J.S. Perspectives on Halogen Bonding and Other Sigma-Hole Interactions: Lex Parsimoniae (Occam's Razor). Comput. Theor. Chem. 2012, 998, 2-8. [CrossRef]

8. Politzer, P.; Murray, J.S. Halogen Bonding: An Interim Discussion. ChemPhysChem 2013, 14, $278-294$. [CrossRef] [PubMed]

9. Kolar, M.H.; Hobza, P. Computer Modeling of Halogen Bonds and Other Sigma-Hole Interactions. Chem. Rev. 2016, 116, 5155-5187. [CrossRef] [PubMed]

10. Fanfrlik, J.; Holub, J.; Ruzickova, Z.; Rezac, J.; Lane, P.D.; Wann, D.A.; Hnyk, D.; Ruzicka, A.; Hobza, P. Competition between Halogen, Hydrogen and Dihydrogen Bonding in Brominated Carboranes. Chemphyschem 2016, 17, 3373-3376. [CrossRef] [PubMed]

11. Pascoe, D.J.; Ling, K.B.; Cockroft, S.L. The Origin of Chalcogen-Bonding Interactions. J. Am. Chem. Soc. 2017, 139, 15160-15167. [CrossRef] [PubMed]

12. Mahmudov, K.T.; Kopylovich, M.N.; Guedes da Silva, M.F.C.; Pombeiro, A.J.L. Chalcogen Bonding in Synthesis, Catalysis and Design of Materials. Dalton Trans. 2017, 46, 10121-10138. [CrossRef] [PubMed]

13. Zhao, H.; Gabbaï, F.P. A Bidentate Lewis Acid with a Telluronium Ion as an Anion-Binding Site. Nat. Chem. 2010, 2, 984-990. [CrossRef] [PubMed]

14. Iwaoka, M.; Isozumi, N. Hypervalent Nonbonded Interactions of a Divalent Sulfur Atom. Implications in Protein Architecture and the Functions. Molecules 2012, 17, 7266-7283. [CrossRef] [PubMed]

15. Mikherdov, A.S.; Novikov, A.S.; Kinzhalov, M.A.; Boyarskiy, V.P.; Starova, G.L.; Ivanov, A.Y.; Kukushkin, V.Y. Halides Held by Bifurcated Chalcogen-Hydrogen Bonds. Effect of $\mu_{(\mathrm{S}, \mathrm{N}-\mathrm{H})} \mathrm{Cl}$ Contacts on Dimerization of $\mathrm{Cl}$ (carbene)Pd ${ }^{\mathrm{II}}$ Species. Inorg. Chem. 2018, in press. [CrossRef]

16. Brezgunova, M.E.; Lieffrig, J.; Aubert, E.; Dahaoui, S.; Fertey, P.; Lebegue, S.; Angyan, J.G.; Fourmigue, M.; Espinosa, E. Chalcogen Bonding: Experimental and Theoretical Determinations from Electron Density Analysis. Geometrical Preferences Driven by Electrophilic-Nucleophilic Interactions. Cryst. Growth Des. 2013, 13, 3283-3289. [CrossRef]

17. Alikhani, E.; Fuster, F.; Madebene, B.; Grabowski, S.J. Topological Reaction Sites-Very Strong Chalcogen Bonds. Phys. Chem. Chem. Phys. 2014, 16, 2430-2442. [CrossRef] [PubMed]

18. Thomas, S.P.; Veccham, S.P.K.P.; Farrugia, L.J.; Row, T.N.G. “Conformational Simulation” of Sulfamethizole

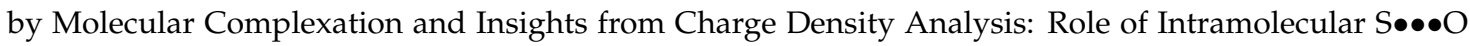
Chalcogen Bonding. Cryst. Growth Des. 2015, 15, 2110-2118. [CrossRef]

19. Sánchez-Sanz, G.; Trujillo, C. Improvement of Anion Transport Systems by Modulation of Chalcogen Interactions: The Influence of Solvent. J. Phys. Chem. A 2018, 122, 1369-1377. [CrossRef] [PubMed]

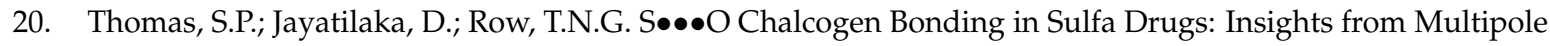
Charge Density and X-Ray Wavefunction of Acetazolamide. Phys. Chem. Chem. Phys. 2015, 17, 25411-25420. [CrossRef] [PubMed]

21. Sanchez-Sanz, G.; Trujillo, C.; Alkorta, I.; Elguero, J. Intermolecular Weak Interactions in HTeXH Dimers $(\mathrm{X}=\mathrm{O}, \mathrm{S}, \mathrm{Se}, \mathrm{Te})$ : Hydrogen Bonds, Chalcogen-Chalcogen Contacts and Chiral Discrimination. Chem. Phys. Chem. 2012, 13, 496-503. [CrossRef] [PubMed]

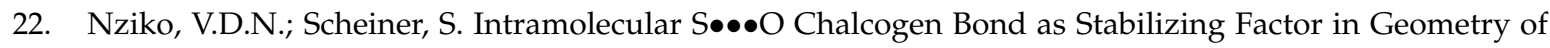
Substituted Phenyl-SF3 Molecules. J. Org. Chem. 2015, 80, 2356-2363. [CrossRef] [PubMed] 
23. Shishkin, O.V.; Omelchenko, I.V.; Kalyuzhny, A.L.; Paponov, B.V. Intramolecular S•••O Chalcogen Bond in Thioindirubin. Struct. Chem. 2010, 21, 1005-1011. [CrossRef]

24. Sanz, P.; Yanez, M.; Mo, O. Resonance-Assisted Intramolecular Chalcogen-Chalcogen Interactions? Chem.-A. Eur. J. 2003, 9, 4548-4555. [CrossRef] [PubMed]

25. Zahn, S.; Frank, R.; Hey-Hawkins, E.; Kirchner, B. Pnicogen Bonds: A New Molecular Linker? Chem.-A. Eur. J. 2011, 17, 6034-6038. [CrossRef] [PubMed]

26. Scheiner, S. The Pnicogen Bond: Its Relation to Hydrogen, Halogen, and Other Noncovalent Bonds. Acc. Chem. Res. 2013, 46, 280-288. [CrossRef] [PubMed]

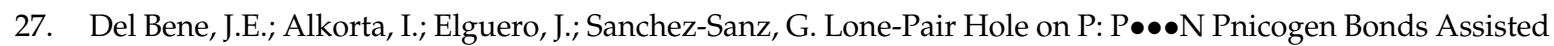
by Halogen Bonds. J. Phys. Chem. A 2017, 121, 1362-1370. [CrossRef] [PubMed]

28. Alkorta, I.; Elguero, J.; Del Bene, J.E. Unusual Acid-Base Properties of The P-4 Molecule in Hydrogen-, Halogen-, and Pnicogen-Bonded Complexes. Phys. Chem. Chem. Phys. 2016, 18, 32593-32601. [CrossRef] [PubMed]

29. Sanchez-Sanz, G.; Trujillo, C.; Alkorta, I.; Elguero, J. Intramolecular Pnicogen Interactions in Phosphorus and Arsenic Analogues of Proton Sponges. Phys. Chem. Chem. Phys. 2014, 16, 15900-15909. [CrossRef] [PubMed]

30. Sanz, D.; Claramunt, R.M.; Mathey, F.; Alkorta, I.; Sanchez-Sanz, G.; Elguero, J. Intermolecular Spin-Spin Coupling Constants Between P-31 Atoms. C. R. Chim. 2013, 16, 937-944. [CrossRef]

31. Del Bene, J.E.; Alkorta, I.; Sanchez-Sanz, G.; Elguero, J. P-31-P-31 Spin-Spin Coupling Constants for Pnicogen Homodimers. Chem. Phys. Lett. 2011, 512, 184-187. [CrossRef]

32. Bauza, A.; Mooibroek, T.J.; Frontera, A. The Bright Future of Unconventional Sigma/-Hole Interactions. Chem. Phys. Chem. 2015, 16, 2496-2517. [CrossRef] [PubMed]

33. Wheeler, S.E. Local Nature of Substituent Effects in Stacking Interactions. J. Am. Chem. Soc. 2011, 133, 10262-10274. [CrossRef] [PubMed]

34. Wheeler, S.E. Understanding Substituent Effects in Noncovalent Interactions Involving Aromatic Rings. Acc. Chem. Res. 2013, 46, 1029-1038. [CrossRef] [PubMed]

35. Martinez, C.R.; Iverson, B.L. Rethinking the term "pi-stacking". Chem. Sci. 2012, 3, 2191-2201. [CrossRef]

36. Trujillo, C.; Sanchez-Sanz, G. A Study of pi-pi Stacking Interactions and Aromaticity in Polycyclic Aromatic Hydrocarbon/Nucleobase Complexes. Chem. Phys. Chem. 2016, 17, 395-405. [CrossRef] [PubMed]

37. Blanco, F.; Kelly, B.; Sanchez-Sanz, G.; Trujillo, C.; Alkorta, I.; Elguero, J.; Rozas, I. Non-Covalent Interactions: Complexes of Guanidinium with DNA and RNA Nucleobases. J. Phys. Chem. B 2013, 117, 11608-11616. [CrossRef] [PubMed]

38. Dougherty, D.A.Y. The Cation- $\pi$ Interaction. Acc. Chem. Res. 2013, 46, 885-893. [CrossRef] [PubMed]

39. Ma, J.C.; Dougherty, D.A. The Cation- $\pi$ Interaction. Chem. Rev. 1997, 97, 1303-1324. [CrossRef] [PubMed]

40. Mahadevi, A.S.; Sastry, G.N. Cation- $\pi$ Interaction: Its Role and Relevance in Chemistry, Biology, and Material Science. Chem. Rev. 2013, 113, 2100-2138. [CrossRef] [PubMed]

41. Schottel, B.L.; Chifotides, H.T.; Dunbar, K.R. Anion- $\pi$ Interactions. Chem. Soc. Rev. 2008, 37, 68-83. [CrossRef] [PubMed]

42. López-Andarias, J.; Frontera, A.; Matile, S. Anion- $\pi$ Catalysis on Fullerenes. J. Am. Chem. Soc. 2017, 139, 13296-13299. [CrossRef] [PubMed]

43. Yam, V.W.-W.; Au, V.K.-M.; Leung, S.Y.-L. Light-Emitting Self-Assembled Materials Based on d8 and d10 Transition Metal Complexes. Chem. Rev. 2015, 115, 7589-7728. [CrossRef] [PubMed]

44. Sculfort, S.; Braunstein, P. Intramolecular d10-d10 Interactions in Heterometallic Clusters of The Transition Metals. Chem. Soc. Rev. 2011, 40, 2741-2760. [CrossRef] [PubMed]

45. Eryazici, I.; Moorefield, C.N.; Newkome, G.R. Square-Planar Pd(II), Pt(II), and Au(III) Terpyridine Complexes: Their Syntheses, Physical Properties, Supramolecular Constructs, and Biomedical Activities. Chem. Rev. 2008, 108, 1834-1895. [CrossRef] [PubMed]

46. Bauza, A.; Alkorta, I.; Frontera, A.; Elguero, J. On the Reliability of Pure and Hybrid DFT Methods for the Evaluation of Halogen, Chalcogen, and Pnicogen Bonds Involving Anionic and Neutral Electron Donors. J. Chem. Theory Comput. 2013, 9, 5201-5210. [CrossRef] [PubMed]

47. Wang, W.; Ji, B.; Zhang, Y. Chalcogen Bond: A Sister Noncovalent Bond to Halogen Bond. J. Phys. Chem. A 2009, 113, 8132-8135. [CrossRef] [PubMed] 
48. Bleiholder, C.; Werz, D.B.; Koppel, H.; Gleiter, R. Theoretical Investigations on Chalcogen-Chalcogen Interactions: What Makes These Nonbonded Interactions Bonding? J. Am. Chem. Soc. 2006, 128, $2666-2674$. [CrossRef] [PubMed]

49. Bauza, A.; Quinonero, D.; Deya, P.M.; Frontera, A. Halogen Bonding Versus Chalcogen and Pnicogen Bonding: A Combined Cambridge Structural Database and Theoretical Study. CrystEngComm 2013, 15, 3137-3144. [CrossRef]

50. Cavallo, G.; Metrangolo, P.; Pilati, T.; Resnati, G.; Terraneo, G. Naming Interactions from the Electrophilic Site. Cryst. Growth Des. 2014, 14, 2697-2702. [CrossRef]

51. Bora, P.L.; Novak, M.; Novotny, J.; Foroutan-Nejad, C.; Marek, R. Supramolecular Covalence in Bifurcated Chalcogen Bonding. Chem.-A Eur. J. 2017, 23, 7315-7323. [CrossRef] [PubMed]

52. Nayak, S.K.; Kumar, V.; Murray, J.S.; Politzer, P.; Terraneo, G.; Pilati, T.; Metrangolo, P.; Resnati, G. Fluorination Promotes Chalcogen Bonding in Crystalline Solids. CrystEngComm 2017, 19, 4955-4959. [CrossRef]

53. Lee, L.M.; Corless, V.B.; Tran, M.; Jenkins, H.; Britten, J.F.; Vargas-Baca, I. Synthetic, Structural, and Computational Investigations of N-alkyl benzo-2,1,3-Selenadiazolium Iodides and Their Supramolecular Aggregates. Dalton Trans. 2016, 45, 3285-3293. [CrossRef] [PubMed]

54. Jackson, N.E.; Savoie, B.M.; Kohlstedt, K.L.; de la Cruz, M.O.; Schatz, G.C.; Chen, L.X.; Ratner, M.A. Controlling Conformations of Conjugated Polymers and Small Molecules: The Role of Nonbonding Interactions. J. Am. Chem. Soc. 2013, 135, 10475-10483. [CrossRef] [PubMed]

55. Lee, L.M.; Elder, P.J.W.; Cozzolino, A.F.; Yang, Q.; Vargas-Baca, I. An Experimental And Computational Investigation of The Formation and Structures of N-hydro and N,N'-Dihydro-Benzo-2,1,3-Chalcogenadiazolium Chlorides. Main Group Chem. 2010, 9, 117-133.

56. Schottel, B.L.; Chifotides, H.T.; Shatruk, M.; Chouai, A.; Perez, L.M.; Bacsa, J.; Dunbar, K.R. Anion-pi Interactions as Controlling Elements in Self-Assembly Reactions of Ag(I) Complexes with Pi-Acidic Aromatic Rings. J. Am. Chem. Soc. 2006, 128, 5895-5912. [CrossRef] [PubMed]

57. Suzuki, T.; Fujii, H.; Yamashita, Y.; Kabuto, C.; Tanaka, S.; Harasawa, M.; Mukai, T.; Miyashi, T. Clathrate Formation and Molecular Recognition by Novel Chalcogen Cyano Interactions in Tetracyanoquinodimethanes Fused with Thiadiazole and Selenadiazole Rings. J. Am. Chem. Soc. 1992, 114, 3034-3043. [CrossRef]

58. Mikherdov, A.S.; Kinzhalov, M.A.; Novikov, A.S.; Boyarskiy, V.P.; Boyarskaya, I.A.; Dar'in, D.V.; Starova, G.L.; Kukushkin, V.Y. Difference in Energy between Two Distinct Types of Chalcogen Bonds Drives Regioisomerization of Binuclear (Diaminocarbene)PdII Complexes. J. Am. Chem. Soc. 2016, 138, 14129-14137. [CrossRef] [PubMed]

59. Katkova, S.A.; Kinzhalov, M.A.; Tolstoy, P.M.; Novikov, A.S.; Boyarskiy, V.P.; Ananyan, A.Y.; Gushchin, P.V.; Haukka, M.; Zolotarev, A.A.; Ivanov, A.Y.; et al. Diversity of Isomerization Patterns and Protolytic Forms in Aminocarbene PdII and PtII Complexes Formed upon Addition of N,N'-Diphenylguanidine to Metal-Activated Isocyanides. Organometallics 2017, 36, 4145-4159. [CrossRef]

60. Kinzhalov, M.A.; Legkodukh, A.S.; Anisimova, T.B.; Novikov, A.S.; Suslonov, V.V.; Luzyanin, K.V.; Kukushkin, V.Y. Tetrazol-5-ylidene Gold(III) Complexes from Sequential [2 + 3] Cycloaddition of Azide to Metal-Bound Isocyanides and N4 Alkylation. Organometallics 2017, 36, 3974-3980. [CrossRef]

61. Anisimova, T.B.; Kinzhalov, M.A.; Silva, M.F.C.G.d.; Novikov, A.S.; Kukushkin, V.Y.; Pombeiro, A.J.L.; Luzyanin, K.V. Addition of N-Nucleophiles to Gold(III)-Bound Isocyanides Leading to Short-Lived Gold(III) Acyclic Diaminocarbene Complexes. New J. Chem. 2017, 41, 3246-3250. [CrossRef]

62. Kinzhalov, M.A.; Starova, G.L.; Boyarskiy, V.P. Interaction of Benzene-1,2-Diamines with Isocyanide Complexes of Palladium(II): Insight into the Mechanism. Inorg. Chim. Acta 2017, 455, 607-612. [CrossRef]

63. Kinzhalov, M.A.; Timofeeva, S.A.; Luzyanin, K.V.; Boyarskiy, V.P.; Yakimanskiy, A.A.; Haukka, M.; Kukushkin, V.Y. Palladium(II)-Mediated Addition of Benzenediamines to Isocyanides: Generation of Three Types of Diaminocarbene Ligands Depending on the Isomeric Structure of the Nucleophile. Organometallics 2016, 35, 218-228. [CrossRef]

64. Boyarskiy, V.P.; Bokach, N.A.; Luzyanin, K.V.; Kukushkin, V.Y. Metal-Mediated and Metal-Catalyzed Reactions of Isocyanides. Chem. Rev. 2015, 115, 2698-2779. [CrossRef] [PubMed] 
65. Timofeeva, S.; Kinzhalov, M.; Valishina, E.; Luzyanin, K.; Boyarskiy, V.; Buslaeva, T.; Haukka, M.; Kukushkin, V. Application of Palladium Complexes Bearing Acyclic Amino(Hydrazido)Carbene Ligands as Catalysts for Copper-Free Sonogashira Cross-Coupling. J. Catal. 2015, 329, 449-456. [CrossRef]

66. Kinzhalov, M.; Boyarskiy, V.; Luzyanin, K.; Dolgushin, F.; Kukushkin, V. Metal-Mediated Coupling of a Coordinated Isocyanide and Indazoles. Dalton Trans. 2013, 42, 10394-10397. [CrossRef] [PubMed]

67. Valishina, E.A.; Guedes da Silva, M.F.C.; Kinzhalov, M.A.; Timofeeva, S.A.; Buslaeva, T.M.; Haukka, M.; Pombeiro, A.J.L.; Boyarskiy, V.P.; Kukushkin, V.Y.; Luzyanin, K.V. Palladium-ADC Complexes as Efficient Catalysts in Copper-Free and Room Temperature Sonogashira Coupling. J. Mol. Catal. A: Chem. 2014, 395, 162-171. [CrossRef]

68. Kinzhalov, M.; Luzyanin, K.; Boyarskiy, V.; Haukka, M.; Kukushkin, V. ADC-Based Palladium Catalysts for Aqueous Suzuki Miyaura Cross-Coupling Exhibit Greater Activity than the Most Advantageous Catalytic Systems. Organometallics 2013, 32, 5212-5223. [CrossRef]

69. Bikbaeva, Z.M.; Ivanov, D.M.; Novikov, A.S.; Ananyev, I.V.; Bokach, N.A.; Kukushkin, V.Y. Electrophilic-Nucleophilic Dualism of Nickel(II) toward Ni ‥ I Noncovalent Interactions: Semicoordination of Iodine Centers via Electron Belt and Halogen Bonding via $\sigma$-Hole. Inorg. Chem. 2017, 56, 13562-13578. [CrossRef] [PubMed]

70. Adonin, S.A.; Gorokh, I.D.; Novikov, A.S.; Abramov, P.A.; Sokolov, M.N.; Fedin, V.P. Halogen Contacts-Induced Unusual Coloring in Bi-III Bromide Complex: Anion-to-Cation Charge Transfer via

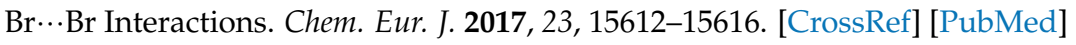

71. Ivanov, D.M.; Kinzhalov, M.A.; Novikov, A.S.; Ananyev, I.V.; Romanova, A.A.; Boyarskiy, V.P.; Haukka, M.; Kukushkin, V.Y. $\mathrm{H}_{2} \mathrm{C}(\mathrm{X})-\mathrm{X} \cdots \mathrm{X}-(\mathrm{X}=\mathrm{Cl}, \mathrm{Br})$ Halogen Bonding of Dihalomethanes. Cryst. Growth Des. 2017, 17, 1353-1362. [CrossRef]

72. Novikov, A.S.; Ivanov, D.M.; Avdontceva, M.S.; Kukushkin, V.Y. Diiodomethane as a Halogen Bond Donor Toward Metal-Bound Halides. CrystEngComm 2017, 19, 2517-2525. [CrossRef]

73. Ivanov, D.M.; Novikov, A.S.; Ananyev, I.V.; Kirina, Y.V.; Kukushkin, V.Y. Halogen Bonding between Metal Centers and Halocarbons. Chem. Commun. 2016, 52, 5565-5568. [CrossRef] [PubMed]

74. Ding, X.; Tuikka, M.J.; Hirva, P.; Kukushkin, V.Y.; Novikov, A.S.; Haukka, M. Fine-Tuning Halogen Bonding Properties Of Diiodine Through Halogen-Halogen Charge Transfer-Extended [Ru(2,2'-Bipyridine)(CO)2X2]ᄀ“,àëI2 Systems (X = Cl, Br, I). CrystEngComm 2016, 18, 1987-1995. [CrossRef]

75. Ivanov, D.M.; Novikov, A.S.; Starova, G.L.; Haukka, M.; Kukushkin, V.Y. A Family of Heterotetrameric Clusters of Chloride Species and Halomethanes Held by Two Halogen and Two Hydrogen Bonds. CrystEngComm 2016, 18, 5278-5286. [CrossRef]

76. Mikhaylov, V.N.; Sorokoumov, V.N.; Korvinson, K.A.; Novikov, A.S.; Balova, I.A. Synthesis and Simple Immobilization of Palladium(II) Acyclic Diaminocarbene Complexes on Polystyrene Support as Efficient Catalysts for Sonogashira and Suzuki-Miyaura Cross-Coupling. Organometallics 2016, 35, 1684-1697. [CrossRef]

77. Serebryanskaya, T.V.; Novikov, A.S.; Gushchin, P.V.; Haukka, M.; Asfin, R.E.; Tolstoy, P.M.; Kukushkin, V.Y. Identification and $\mathrm{H}(\mathrm{D})$-Bond Energies of C-H(D)Center Dot Center Dot Center Dot CL Interactions in Chloride-Haloalkane Clusters: A Combined X-ray Crystallographic, Spectroscopic, and Theoretical Study. Phys. Chem. Chem. Phys. 2016, 18, 14104-14112. [CrossRef] [PubMed]

78. Sheldrick, G.M. A short history of SHELX. Acta Crystallogr. Sect. A: Found. Crystallogr. 2008, 64, 112-122. [CrossRef] [PubMed]

79. Dolomanov, O.; Bourhis, L.; Gildea, R.; Howard, J.; Puschmann, H. OLEX2: A Complete Structure Solution, Refinement and Analysis Program. J. Appl. Crystallogr. 2009, 42, 339-341. [CrossRef]

80. CrysAlisPro; 1.171.36.20; Agilent Technologies: Yarnton, Oxfordshire, UK, 2012.

81. Spek, A.L. Platon Squeeze: A Tool for the Calculation of the Disordered Solvent Contribution to the Calculated Structure Factors. Acta Crystallogr. Sect. C Struct. Chem. 2015, 71, 9-18. [CrossRef] [PubMed]

82. Wolff, S.K.; Grimwood, D.J.; McKinnon, J.J.; Turner, M.J.; Jayatilaka, D.; Spackman, M.A. CrystalExplorer, Version 3.1; University of Western Australia: Perth, Australia, 2012.

83. Spackman, M.A.; Jayatilaka, D. Hirshfeld Surface Analysis. CrystEngComm 2009, 11, 19-32. [CrossRef]

84. McKinnon, J.J.; Jayatilaka, D.; Spackman, M.A. Towards Quantitative Analysis of Intermolecular Interactions with Hirshfeld Surfaces. Chem. Commun. 2007, 37, 3814-3816. [CrossRef]

85. Bondi, A. Van Der Waals Volumes + RadiI. J. Phys. Chem. 1964, 68, 441-451. [CrossRef] 
86. Nakajima, T.; Hirao, K. The Douglas-Kroll-Hess Approach. Chem. Rev. 2012, 112, 385-402. [CrossRef] [PubMed]

87. Reiher, M. Relativistic Douglas-Kroll-Hess Theory. Wiley Interdiscip. Rev. Comput. Mol. Sci. 2012, 2, 139-149. [CrossRef]

88. Frisch, M.J.; Trucks, G.W.; Schlegel, H.B.; Scuseria, G.E.; Robb, M.A.; Cheeseman, J.R.; Scalmani, G.; Barone, V.; Mennucci, B.; Petersson, G.A.; et al. Gaussian 09, Revision C.01; Gaussian, Inc.: Wallingford, CT, USA, 2010.

89. Bader, R.F.W. A Quantum-Theory of Molecular-Structure and Its Applications. Chem. Rev. 1991, 91, 893-928. [CrossRef]

90. Lu, T.; Chen, F.W. Multiwfn: A Multifunctional Wavefunction Analyzer. J. Comput. Chem. 2012, 33, 580-592. [CrossRef] [PubMed]

91. Glendening, E.D.; Landis, C.R.; Weinhold, F. Natural Bond Orbital Methods. Wiley Interdiscip. Rev. Comput. Mol. Sci. 2012, 2, 1-42. [CrossRef]

92. Rowland, R.S.; Taylor, R. Intermolecular Nonbonded Contact Distances in Organic Crystal Structures: Comparison with Distances Expected from Van Der Waals Radii. J. Phys. Chem. 1996, 100, 7384-7391. [CrossRef]

93. Burling, F.T.; Goldstein, B.M. Computational Studies of Nonbonded Sulfur Oxygen and Selenium Oxygen Interactions in the Thiazole and Selenazole Nucleosides. J. Am. Chem. Soc. 1992, 114, 2313-2320. [CrossRef]

94. Rosenfield, R.E.; Parthasarathy, R.; Dunitz, J.D. Directional Preferences of Nonbonded Atomic Contacts with Divalent Sulfur. 1. Electrophiles and Nucleophiles. J. Am. Chem. Soc. 1977, 99, 4860-4862. [CrossRef]

95. Arunan, E.; Desiraju, G.R.; Klein, R.A.; Sadlej, J.; Scheiner, S.; Alkorta, I.; Clary, D.C.; Crabtree, R.H.; Dannenberg, J.J.; Hobza, P.; et al. Definition of the Hydrogen Bond (IUPAC Recommendations 2011). Pure Appl. Chem. 2011, 83, 1637-1641. [CrossRef]

96. Shukla, R.; Chopra, D. Crystallographic and Theoretical Investigation on the Nature and Characteristics of

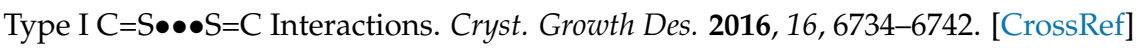

97. Allinger, N.L.; Zhou, X.F.; Bergsma, J. Molecular Mechanics Parameters. J. Mol. Struct. Theochem 1994, 118, 69-83. [CrossRef]

98. Newberry, R.W.; Raines, R.T. The $n \rightarrow \pi^{*}$ Interaction. Acc. Chem. Res. 2017, 50, 1838-1846. [CrossRef] [PubMed]

99. Wang, H.; Wang, W.; Jin, W.J. $\sigma$-Hole Bond vs $\pi$-Hole Bond: A Comparison Based on Halogen Bond. Chem. Rev. 2016, 116, 5072-5104. [CrossRef] [PubMed]

100. Singh, S.K.; Das, A. The $\mathrm{n}->$ pi $^{*}$ interaction: A Rapidly Emerging Non-Covalent Interaction. Phys. Chem. Chem. Phys. 2015, 17, 9596-9612. [CrossRef] [PubMed]

101. Johnson, E.R.; Keinan, S.; Mori-Sánchez, P.; Contreras-García, J.; Cohen, A.J.; Yang, W. Revealing Noncovalent Interactions. J. Am. Chem. Soc. 2010, 132, 6498-6506. [CrossRef] [PubMed]

102. Espinosa, E.; Molins, E.; Lecomte, C. Hydrogen Bond Strengths Revealed by Topological Analyses of Experimentally Observed Electron Densities. Chem. Phys. Lett. 1998, 285, 170-173. [CrossRef]

103. Vener, M.V.; Egorova, A.N.; Churakov, A.V.; Tsirelson, V.G. Intermolecular Hydrogen Bond Energies in Crystals Evaluated Using Electron Density Properties: DFT Computations with Periodic Boundary Conditions. J. Comput. Chem. 2012, 33, 2303-2309. [CrossRef] [PubMed]

104. Espinosa, E.; Alkorta, I.; Elguero, J.; Molins, E. From Weak to Strong Interactions: A Comprehensive Analysis

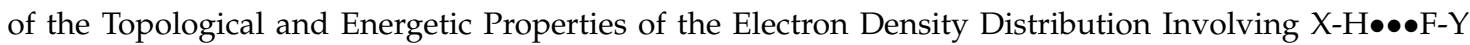
Systems. J. Chem. Phys. 2002, 117, 5529-5542. [CrossRef]

(C) 2018 by the authors. Licensee MDPI, Basel, Switzerland. This article is an open access article distributed under the terms and conditions of the Creative Commons Attribution (CC BY) license (http://creativecommons.org/licenses/by/4.0/). 